\title{
THOU QUEEN OF RIVERS, RARITAN!
}

One of our learned Correspondents recently favored the Editor witb some fruits of bis Researches wbicb we believe will prove of interest to Rutgers Antiquaries. Thougb the $W$ riter signed bis letter by a nom de plume, we bave identified bim as a certain Student of topograpbical Poetry who bas for some years been a Member of the Faculty of the New Fersey College for Women.

To Rudolf Kirk, Esq.

Professor at the College of Queen's in the Town of New-Brunswick Honoured Sir:

I who now write to you am a Man of small Learning and little Wit, who, none the less, fosters a Tenderness toward all-even among the gentle Sex - who profess and call themselves Servants of the Nine. As I sat in my Grotto of late, my man Prateapace conveyed to me a Parcel of Papers which I at once perused. I derived no slight Satisfaction from an Edict issued by our former Governor ordaining that "all women, of whatever age, profession, or rank, whether maids or widows, who shall, after this Act, impose upon, seduce, or betray into matrimony any of His Majesty's subjects, by virtue of scents, cosmetics, washes, paints, artificial teeth, false hair, or high-heeled shoes, shall incur the penalty now in force against witchcraft and like misdemeanours." Down, saeva indignatio, down. Can such things be? Surely the female World should ponder and inwardly digest the Portrait of Maria (how like, ye Loves, to my own Amanda) in the little Effusion contained in another of these Papers which I hasten to dispatch to you that, ere it be too late, you may hold up to those young Gentlemen in statu pupillari, to whom you stand in loco parentis, a mirror of true female Modesty and Worth. I have, moreover, assumed the unwonted Liberty of forwarding another set of Verses in which, albeit that Lactilla and not Bacchus hath touched the Bard's trembling Ear, all true Lovers of Poesy will discern a Heart that feels and Tears that flow. And now, Honoured Sir, I take my leave that I may direct to the learned Editor of the Times the fervent Hope that our invincible Cburcbill may continue, as formerly with the great Eugene, to ride the whirlwind and direct the storm.

$$
\text { I am, Sir, }
$$

Your Constant Reader, And Well-wisher:

SERENITAS

The following verses which were written several years ago, the author never designed to publish; but having got possession of them, I cannot withhold from my readers a specimen of my friend's early genius. If my partiality does not deceive me, they will be found to breath [sic] the genuine spirit of Love and Poetry. 


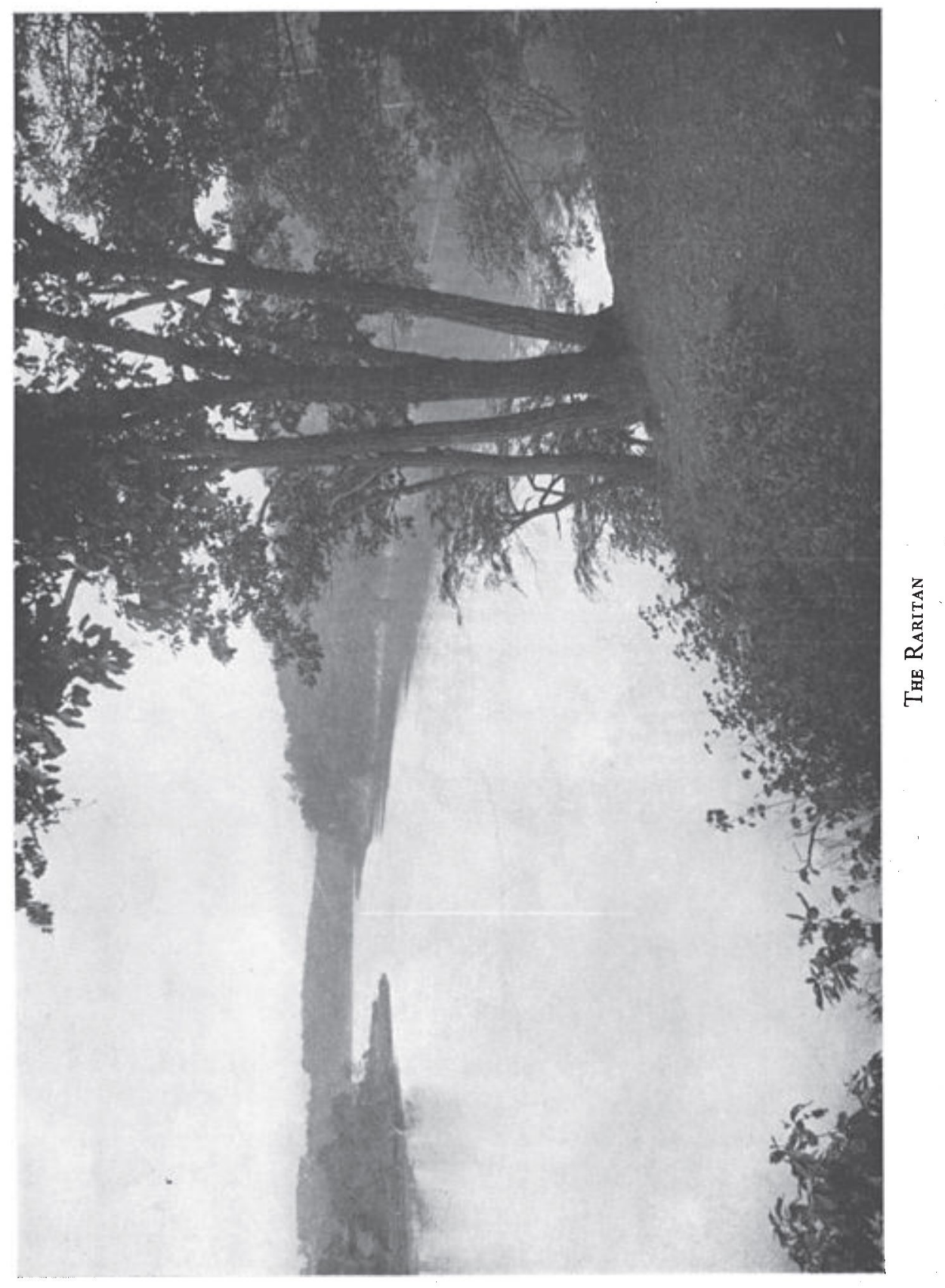




\section{Address to the River Rariton ${ }^{1}$}

Hail, Rariton, the boast of Fersey's plain, Of all thy numerous sister streams the pride,

That roll, their names unaltered to the main, Or lose them, wedded to some mightier tide.

Oft have I seen thee from thy humble spring Where wood-crown'd Scbooley, ${ }^{*}$ rears his rugged head, O'er his black rocks thy whiten'd torrent fling, And rage impetuous thro' thy broken bed.

Then lost in woods, imperious shape thy way, Heard loud (sweet nature's Music) though unseen, Till smoothed, yet rapid, rushing into day, Paint the gay Heavens in thy glassy plain.

Still as thou wind'st along the smiling vale, And bending striv'st t'extend thy fost'ring sway, Each grateful field assumes a deeper green, And by adoring hastens to repay.

The tow'ring Hemlocks interpose their shade, And on thy banks the Conic Cedars rise, To keep thee tranquil in thy lowly bed, While the loud tempest sweeps athwart the skies.

Oh, let me still thy sinuous course pursue, While many a sudden bend, still cheats my wayAgain thou meet'st my long enquiring view, Where the gay sunbeams on thy waters play.

Thence let me trace thee, where in gay increase Thou visit'st Sidney's hospitable dome;Dear seat of plenty, health, and rural peace; And every pleasure virtue calls her own.

But chief, of beauty-blest with ev'ry grace

That sportive nature to her fav'rite gives: An angel's person; and an angel's face, An angel's mind;--'tis here Maria lives.

With every charm that cities can impart, Maria boasts what cities cannot show;

\footnotetext{
I Frankly, "Address to the Rariton [sic]," The Companion and Weekly Miscellany (Baltimore), I, 207-208 (no. 26, Sat., April 27, I805).

* (Scbooley) a mountain in Fersey.
} 
Unwarped simplicity, a guileless heart, Pure and unsullied as the virgin snow.

All-lovely Nature! still thou warm'st my breast, Though clothed in tatters at the cottage door: But, when in Heav'ns own radiant image drest, T'admire is cold! - I hail thee and adore!

Can all the slipp'ry polish art affords, Th' obedient smile that waits at will to start; The phrase composed with all the pomp of wordsPay for one warm effusion of the heart.

Pay for the smile illumining the face,

With sweet contagion spreading all around;

The hand frank-offered, whose untutored grace

Expects a friend, and welcomes him when found;

Let me kind Heaven, if it be my lot

From youth to age the whole long course to run, Find nature a companion in my cot;

And toss to kings their sceptre and their crown.

Flow on loved Rariton!- to other scenes

Thy tributary waste of beauties pour-

No banks can grace thee like these happy plains, No verdure crown thee as on Sidney's shore.

No eye so bright as fair Maria's trace

Thy tangled current glitt'ring 'neath the beam;

No form so fair, reflected in thy face,

Shall look the smiling goddess of the stream.

Flow murmuring on-too soon to quit the shades, And sylvan honors that adorned thy wave; The Prow too soon thy tranquil breast invades, And busy commerce claims thee as its slave.

\section{Ode to the River Raritan ${ }^{2}$}

Lost in a pleasing wild surprise,

I mark the fountains round me rise;

${ }^{2}$ These verses were communicated to the Editor of the European Magazine [London, Vol. XLIX (May, I806), 373-4] with the accompanying note:

Sir,

Visiting, last winter, my friend Mr. George, at Raritan, in New Jersey, I wrote an Ode to the River. I now take the liberty to transmit it to you considerably enlarged, and, I flatter myself, somewhat revised and corrected.

Accept my kind salutations.

New York, January 4, I 806. 
And in an artless current flow

Thro' dark and lofty woods below,

That from the world the soul confine,

And raise the thought to things divine.

O sacred stream! a stranger I

Would stay to see thee passing by,

And mark thee wandering thus alone,

With varied turns so like my own!

Wild, as a stranger led astray,

I see thee wind in woods away,

And hasting thro' the trees to glide,

As if thy gentle face to hide.

While oft in vain thou wouldst return,

To visit here thy native urn:

But like an exile doom'd no more

To see the scenes he lov'd before,

You wander on, and wind in vain,

Dispers'd amid the boundless main.

Here often on thy borders green,

Perhaps thy native sons were seen,

Ere slaves were made, or gold was known,

Or children from another zone

Inglorious did, with axes rude,

Into thy noble groves intrude,

And forc'd thy naked son to flee

To woods where he might still be free.

And thou! that art my present theme,

$\mathrm{O}$ gentle spirit of the stream!

Then too, perhaps, to thee was given

A name among the race of heaven;

And oft ador'd by Nature's child

Whene'er he wander'd in the wild.

And oft, perhaps, beside the flood,

In darkness of the grove he stood;

Invoking here thy friendly aid

To guide him thro' the doubtful shade:

Till overhead the moon in view

Thro' heaven's blue fields the chariot drew,

And show'd him all thy wat'ry face,

Reflected with a purer grace;

Thy many turnings thro' the trees,

Thy bitter journey to the seas.

While oft thy murmurs loud and long

Awak'd his melancholy song;

Which thus in simple strain began,

"Thou Queen of Rivers, Raritan!" 